\title{
コンクリートに埋め込まれた金属系アンカーの \\ 引抜き特性に及ぼす高温加熱の影響 \\ INFLUENCE OF HIGH TEMPERATURE HEATING ON PULL-OUT PROPERTIES OF MECHANICAL ANCHOR EMBEDDED IN CONCRETE
}

\author{
松沢晃一*，橘高義典 ${ }^{*}$, 刈田祥彦*** \\ Koichi MATSUZAWA, Yoshinori KITSUTAKA and Akihiko KATTA
}

\begin{abstract}
Surface layer of concrete becomes the most heavily damaged part affected by high temperature heating when concrete structure is subjected to fire accident. In the surface layer of concrete structures, the anchor bolts are used for fixing the equipment or the seismic strengthening elements. This paper reports on the investigation into the influence of high temperature heating up to $1000^{\circ} \mathrm{C}$ on pull-out properties of two types of mechanical anchor embedded in concrete. Relationship between the pull-out strength of anchors and the fracture energy was also investigated.
\end{abstract}

Keywords : Mechanical anchor, Pull-out properties, High temperature heating, Concrete, Fracture energy 金属系アンカー, 引抜き特性, 高温加熱, コンクリート, 破壊エネルギー

\section{1. はじめに}

現在，様々な用途に用いられているコンクリート構造物は，供用 期間中に多くの劣化因子の影響を受けるが，その劣化因子の 1 つに 熱がある。コンクリートは熱の影響を受けると強度特性などの性質 が変化するため，長期にわたり熱の影響を受ける焼却施設や発電所 施設などでは，供用時のコンクリートに対して温度制限值が設けら れている場合がある ${ }^{1)}$ 。また，火災時においても，高温加熱の影響 によりコンクリートの性質は変化する。そのため, 熱の影響を受け たコンクリートに関しては多くの検討がなされている。圧縮強度や 引張強度は，加熱温度の上昇や，それにともなう含水状態によって 変化し，高温になるほど低下すること ${ }^{2)-10)}$, そして, 引張強度の低

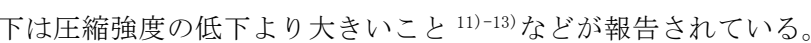

熱の影響を受けたコンクリートの検討に関しては, 破壊力学的手 法を用いた検討もなされており，試験材齢，加熱温度，加熱期間を 変えた切欠き梁 3 点曲げ試験では, 破壊エネルギーは温度上昇とと もに増加し， $300^{\circ} \mathrm{C}$ を境に低下寸ること, 養生期間 28 日までは破壊 エネルギーが増加すること ${ }^{14)-16)}$, また, くさび割裂試験では, 破壊 エネルギーは $450^{\circ} \mathrm{C}$ でピークに達し，その後は低下寸ることなどが 報告されている ${ }^{17)}$ 。そして, 著者ら ${ }^{18), 19)}$ は, コンクリート強度, 試験材齢，養生条件を変化させたくさび割裂試験により，試験条件 と, 破壊勒性試験から得られる破壊パラメータである初期結合応力 および破壊エネルギーとの関係について検討している。
コンクリート構造物が，火災などにより最も熱の影響を受ける部 分は，受熱部である部材の表層部であるが，その表層部には設備機 器の固定や耐震補強などの用途のために，アンカーボルト（以下， アンカー）が用いられている場合が少なくない。前述のとおり，コ ンクリートは熱の影響を受けると強度特性などの性質が変化するた め，表層部に施工されているアンカーの引抜き特性も変化すること が予想される。

アンカーに関しては，工法，種類が多様であり設計指針も刊行さ れている20)。その中には，熱に関する検討がなされているものもあ る。頭付きアンカーに関する検討では，加熱時の最高温度 $500^{\circ} \mathrm{C}$, 埋め込み深さ $30 \mathrm{~mm}$ につて, 加熱中および加熱冷却後の引抜き試 験を行っており，一定引張荷重が作用しているアンカーは高温加熱 により破壊すること，加熱冷却後であっても，アンカーの引抜き荷 重は加熱温度に比例して低下し, 加熱温度 $500^{\circ} \mathrm{C}$ での引抜き荷重は, 常温時と比較して約 $50 \%$ となることが報告されている ${ }^{21)}$ 。接着系あ と施工アンカーに関する検討 ${ }^{22)}$ では，かぶり厚さを変化させてコン クリート中に埋め込んだエポキシ樹脂被覆アンカーについて, 加熱 時の温度 $1050^{\circ} \mathrm{C}$, 加熱時間 3 時間の加熱時の温度変化の測定および 自然除熱した後に引抜き試験が行われている。その結果，アンカー の表面温度を $200^{\circ} \mathrm{C}$ 以下に抑制するには，かぶり厚さ $100 \mathrm{~mm}$ 以上， $100^{\circ} \mathrm{C}$ 以下にするためにはかぶり厚さ $200 \mathrm{~mm}$ 以上が必要であるこ とが報告されている。
$*$ 首都大学東京大学院都市環境科学研究科建築学域 助教・修士 (工学)

** 首都大学東京大学院都市環境科学研究科建築学域 教授・ 工博

*** 首都大学東京大学院都市環境科学研究科建築学域 博士前期課程
Assist. Prof., Dept. of Architecture and Building Engineering, Graduate School of Urban Environmental Sciences, Tokyo Metropolitan Univ., M. Eng.

Prof., Dept. of Architecture and Building Engineering, Graduate School of Urban Environmental Sciences, Tokyo Metropolitan Univ., Dr. Eng.

Graduate Student, Dept. of Architecture and Building Engineering, Tokyo Metropolitan Univ. 
アンカーの引抜き荷重と破壊パラメータである破壊エネルギーと の関係に関しては, Eligehausenら ${ }^{23)}$ が検討を行っている。頭付き アンカーの引抜き荷重について破壊力学による解析を行い, 引抜き 時の自由エネルギー（弾性ひずみエネルギー十破壊エネルギー）の 最小化により引抜き荷重を推定し, 実験結果との相関が高いことを 示している。また, 橘高ら ${ }^{24)}$ は, 様々な粗骨材を用いて作製した強 度の異なるコンクリート中に埋め込まれた頭付きアンカーの引抜き 試験および破壊勒性試験を行い, Eligehausen ${ }^{23)}$ による評価式の 有効性を確認するとともに, アンカー先端の径を考慮した評価式を 提案している。

上述のように，頭付きアンカーや接着系あと施工アンカーに関し ては, 多くはないものの, 高温加熱に対する検討もなされている。 しかし，これらと同様に多く用いられている金属系アンカーに関し ては, 高温加熱に対する検討がなされていないのが現状である。そ こで, 本研究では, $100^{\circ} \mathrm{C}$ から $1000^{\circ} \mathrm{C}$ までの高温環境下に一定時間 曝されたコンクリートに埋め込まれた金属系アンカーの引抜き特性 について検討を行った。さらに, 破壊力学的手法を用いて, 引抜き 荷重と破壊パラメータとの関係について考察を行った。

\section{2. 実験概要}

\section{1 供試体概要}

写真 1 に本研究で用いた金属系アンカー, 表 1 にコンクリートの 使用材料, 表 2 に調合, 表 3 に実験の要因と水準を示す。アンカー は, 金属系アンカーである芯棒打込み式アンカーおよびアンダーカ ット式アンカーの 2 種類（両アンカーとも直径 $10 \mathrm{~mm}$ ）を用い, ア ンカーの埋め込み深さは $30,40,50 \mathrm{~mm}$ とした。コンクリートは, レディーミクストコンクリート工場（神奈川県相模原市）の 2 軸強 制練りミキサ (公称容量 $1.7 \mathrm{~m}^{3}$ ) を用いて製造された, 呼び強度 27 , 目標スランプ $18 \mathrm{~cm}$, 目標空気量 $4.5 \%$ ののを用いた。なお, コン クリートの製造から打込みまでの時間は約 20 分である。

供試体は, 各試験条件につき, 圧縮およびヤング係数測定用供試 体 $(\phi 100 \times 200 \mathrm{~mm}) 3$ 体，破壊勒性試験用供試体 $(100 \times 100 \times$ $120 \mathrm{~mm}) 3$ 体, アンカーの引抜き試験用供試体 $(250 \times 250 \times 150 \mathrm{~mm})$ 3 体とした。供試体は打込夕後 2 日で脱型し, 材齢 13 週まで標準養 生を行い，加熱および各試験を行った。表 4 にフレッシュ性状と材 齢 4 週および 13 週標準養生後の強度試験結果を示す。

金属系アンカーの施工には, 通常, ハンマーが用いられるが，そ の場合, アンカーに対して垂直方向から衝撃を与えること, また, 打撃による衝撃荷重を一定に保つことが困難であるため, 施工誤差 が実験結果に与える影響が懸念された。そこで，本研究では，油圧 式万能試験機を用いてアンカーを施工することとした。施工時には, 荷重と試験機の変位を測定し, アンカーの拡張が完了点到達後 $2 \mathrm{kN}$ 増した時点で載荷を終了することとした。図 1 に結果例を示す。芯 棒打込み式が 3 段階, アンダーカット式が 2 段階の荷重上昇を示し ているが，これは，拡張部内側が芯棒打込み式で 3 段階, アンダー カット式で 2 段階拡張する構造となっているためである。また, 芯 棒打込み式と比較して, アンダーカット式の拡張完了時点での荷重 が低いのは，削孔による拡張部の穴径が異なるためである。なお， アンカーは引抜き試験用供試体のコンクリート打込夕側面 $(250 \times$ $250 \mathrm{~mm}$ ) 2 面に行った（図 2)。

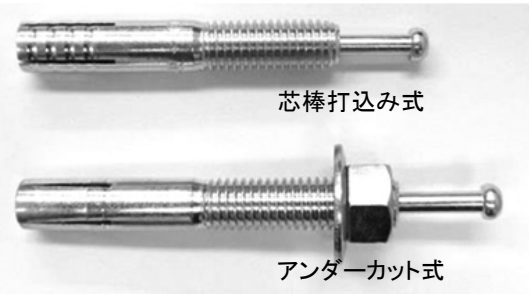

写真 1 金属系アンカー

表 1 使用材料

\begin{tabular}{|c|c|c|c|}
\hline 材料 & 種類 & 記号 & 物性 \\
\hline セメント & 普通ポルトランドセメント & $\mathrm{C}$ & 密度 $3.16 \mathrm{~g} / \mathrm{cm}^{3}$ \\
\hline \multirow{3}{*}{ 細骨材 } & 砕砂（相模原産） & S1 & 表乾密度 $2.63 \mathrm{~g} / \mathrm{cm}^{3}$, 粗粒率 3.00 \\
\hline & 哗砂（八王子産） & S2 & 表乾密度 $2.63 \mathrm{~g} / \mathrm{cm}^{3}$, 粗粒率 3.00 \\
\hline & 山砂（富津産） & S3 & 表乾密度 $2.63 \mathrm{~g} / \mathrm{cm}^{3}$, 粗粒率 1.60 \\
\hline \multirow{2}{*}{ 粗骨材 } & 砕石（相模原産） & G1 & 表乾密度 $2.66 \mathrm{~g} / \mathrm{cm}^{3}$, 実積率 $60.0 \%$ \\
\hline & 砕石（八王子産） & G2 & 表乾密度 $2.66 \mathrm{~g} / \mathrm{cm}^{3}$, 実積率 $60.0 \%$ \\
\hline 混和剤 & 高性能 $\mathrm{AE}$ 減水剤 & $\mathrm{Ad}$ & ポリカルボン酸系化合物 \\
\hline
\end{tabular}

表 2 調合 (単位: $\mathrm{kg} / \mathrm{m}^{3}$ )

\begin{tabular}{c|c|c|c|c|c|c|c|c|c|c|c|c}
\hline $\begin{array}{c}\mathrm{G}_{\max } \\
(\mathrm{mm})\end{array}$ & $\begin{array}{c}\text { スランプ } \\
(\mathrm{cm})\end{array}$ & $\begin{array}{c}\text { 空気量 } \\
(\%)\end{array}$ & $\begin{array}{c}\mathrm{W} / \mathrm{C} \\
(\%)\end{array}$ & $\begin{array}{c}\mathrm{s} / \mathrm{a} \\
(\%)\end{array}$ & $\mathrm{W}$ & $\mathrm{C}$ & $\mathrm{S} 1$ & $\mathrm{~S} 2$ & $\mathrm{~S} 3$ & $\mathrm{G} 1$ & $\mathrm{G} 2$ & $\mathrm{Ad}$ \\
\hline 20 & 18 & 4.5 & 56.8 & 49.0 & 175 & 309 & 351 & 307 & 220 & 463 & 463 & 2.78 \\
\hline
\end{tabular}

表 3 実験の要因と水準

\begin{tabular}{c|c}
\hline 要因 & 水準 \\
\hline アンカー種類 & 芯棒打込み式, アンダーカット式 \\
\hline アンカー埋め込み深さ $(\mathrm{mm})$ & $30,40,50$ \\
\hline 加熱時最高温度 $\left({ }^{\circ} \mathrm{C}\right)$ & $100,200,300,500,800,1000$ \\
\hline
\end{tabular}

表 4 フレッシュ性状および強度試験結果

\begin{tabular}{c|c|c|c|c|c}
\hline \multirow{2}{*}{$\begin{array}{c}\text { スランプ } \\
(\mathrm{cm})\end{array}$} & \multirow{2}{*}{$\begin{array}{c}\text { 空気量 } \\
(\%)\end{array}$} & \multicolumn{2}{|c|}{$\begin{array}{c}\text { 圧縮強度 } \\
\left(\mathrm{N} / \mathrm{mm}^{2}\right)\end{array}$} & \multicolumn{2}{|c}{$\begin{array}{c}\text { ヤング係数 } \\
\left(\mathrm{kN} / \mathrm{mm}^{2}\right)\end{array}$} \\
\cline { 3 - 6 } & & 4 週 & 13 週 & 4 週 & 13 週 \\
\hline 17.5 & 4.9 & 30.4 & 34.5 & 25.2 & 26.4 \\
\hline
\end{tabular}

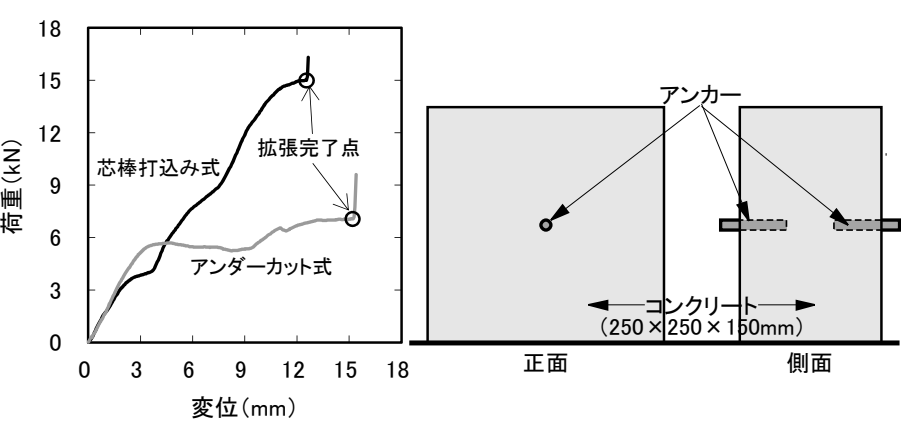

図 1 アンカー施工時の 荷重一変位曲線

図 2 引抜き試験用 供試体概要

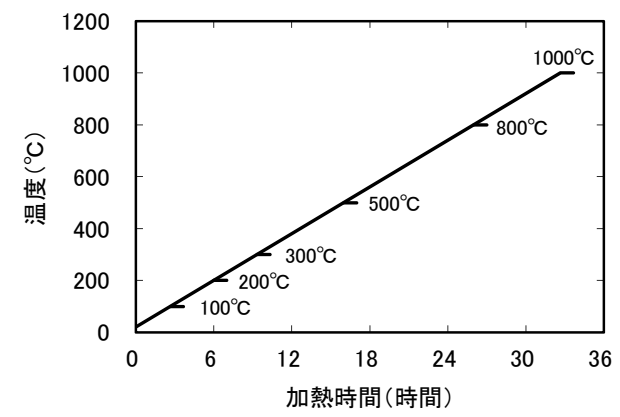

図 3 加熱履歴 


\section{2 加熱方法}

図 3 に炉内での加熱履歴を示す。供試体加熱時の炉内最高温度は $100,200,300,500,800,1000^{\circ} \mathrm{C}$ と, 比較用として加熱なし $\left(20^{\circ} \mathrm{C}\right)$ の供試体についても試験を行った。加熱には, プログラム 調整器付きマッフル炉 (炉内寸法 W $310 \times \mathrm{D} 610 \times \mathrm{H} 310 \mathrm{~mm}$, 左右 2 面加熱）を用いた（図 4)。炉内での均一加熱を行なうために, 供試 体は左右のヒーターからの距離が同一になるよう炉内の中央に設置 した。昇温速度は $0.5^{\circ} \mathrm{C} / \mathrm{min}$ とし, 炉内温度が目標温度に達した後 は, その温度を 1 時間保持して加熱を終了した。そして, 供試体温 度が外気温度と同程度になるまで炉内で自然除熱し, 試験を行った。

図 5 にコンクリートの中心および表面, また, アンカー先端部に $\mathrm{K}$ 型熱電対を設置した供試体を昇温速度 $0.5^{\circ} \mathrm{C} / \mathrm{min}$ で $1000^{\circ} \mathrm{C}$ まで加 熱した際の各部分の温度変化を示す。加熱中はコンクリート表面に 対して, 最大温度差 $20^{\circ} \mathrm{C}$ 程度で内部が温度上昇し, 除熱中の内外温 度差は最大 $50^{\circ} \mathrm{C}$ 程度であった。なお, 炉内温度が $1000^{\circ} \mathrm{C}$ に達して もコンクリート温度は $1000^{\circ} \mathrm{C} に は$ 至らず， $960^{\circ} \mathrm{C}$ 程度であった。

\section{3 試験方法}

\section{3.1 圧縮強度試験}

圧縮強度試験は, JIS A 1108 に準じて行なった。また, 同時にコ ンプレッソメーターを用いてヤング係数を測定した（JIS A 1149）。

\section{3.2 破壊靬性試験}

破壊勒性試験は, 供試体自重の影響や, 炉内での均一加熱を考慮 して, 切久き梁による 3 点曲げ試験方法 ${ }^{25)}$, 26) と同様にモード I 型 (引張型 $)$ の破壊が小型供試体 $(100 \times 100 \times 120 \mathrm{~mm})$ で得られる

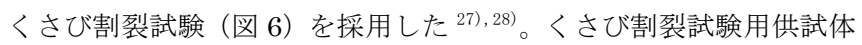
は, 加熱前に供試体中央にダイヤモンドカッター（刃厚 $1 \mathrm{~mm}$ ) を 用いてリガメント高さが $50 \mathrm{~mm}$ となるように切欠きを入れ，くさび の挿入により引張破壊を生じさせることとした。試験に用いた治具 の寸法などは, RILEM で提案されている方法 ${ }^{29}$ に準じた。また, 最大荷重以降の軟化域を精度良く検出するため, 試験には加力部, 油圧装置, フィードバック機能を有する制御装置からなるクローズ ドループシステム型（閉回路機構）のサーボ・コントロール式油圧 試験機（MTS 社製）を用いた。なお，供試体の安定破壊が得られる ように, 切欠き端部の開口変位の変位速度を $0.02 \mathrm{~mm} / \mathrm{min}$ に設定し, 開口変位の計測には変位制御用の高感度クリップゲージを使用した。

\section{3.3 破壊特性の評価}

破壞特性の評価は, くさび割裂試験より得られる荷重一開口変位 (CMOD）曲線を多直線近似法 ${ }^{27)}$, 30)-32) により逆解析して求めた引

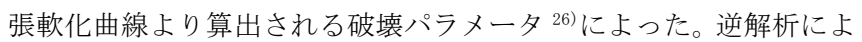
る多直線近似方法は, 実験により求められた荷重一開口変位 (CMOD) 曲線のデータを利用して結合応力一開口変位 (COD) の 関係を非線形ひび割れ方程式の繰り返し演算により求める際に, 計 算により既に求めている一部の結合応力一開口変位 (COD) 関係を 繰り返し演算の構成則として適用し, 逐次解析をする手法を採用し ている。

破壊特性の評価は，破壊パラメータである破壊エネルギーにより 評価した。破壊エネルギーは, 引張軟化曲線で囲まれた面積であり, ひび割れ進展抵抗性を示す值となる。この值が小さいとひび割れは 進展しや寸く, 逆に大きくなると, ひびわれが進展しにくいことを 意味する。

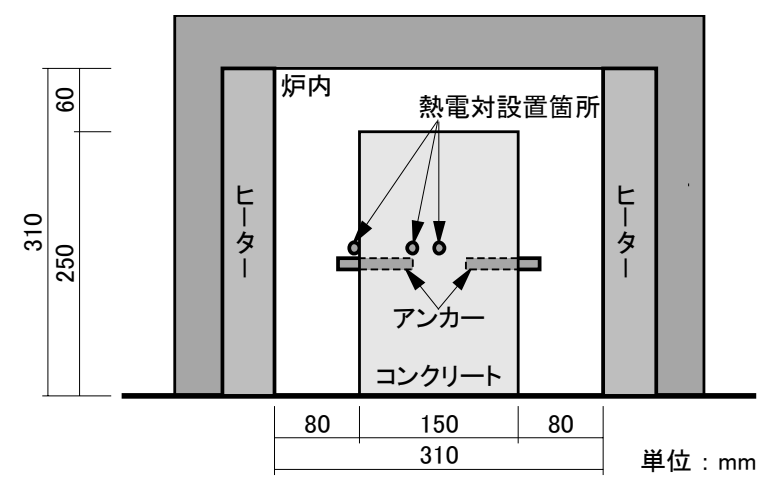

図 4 炉内での供試体配置および熱電対設置箇所

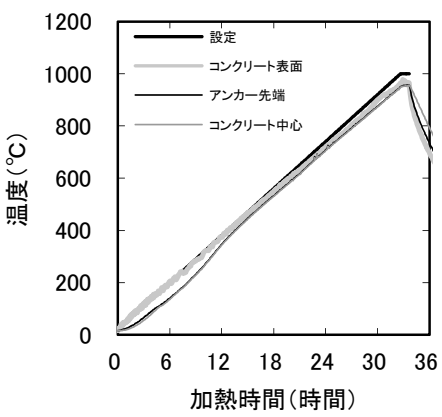

(a) 全体

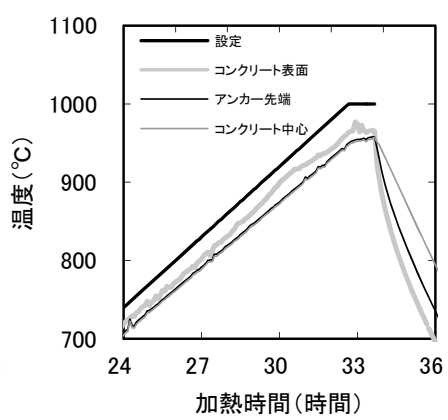

(b) 最大温度周辺
図 5 加熱時の供試体各部分の温度変化

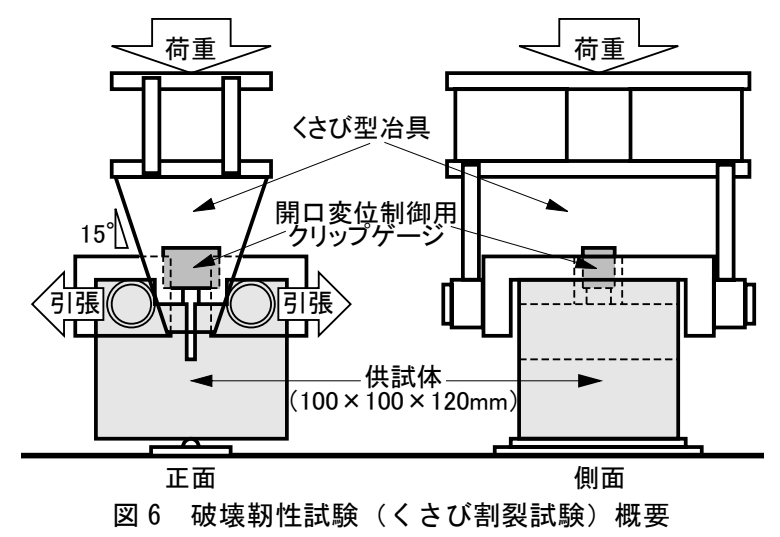

\section{3.4 アンカー引抜き試験}

アンカーの引抜き試験には油圧式引張試験機を用い, 試験時の荷 重および変位を測定した。また，アンカーの破壊特性を検討するた めに, アンカー施工表面の破壊面積, 破壊深さ, 引抜き後のアンカ 一拡張部の径も測定した。

\section{3. 実験結果および考察}

\section{1 コンクリートのカ学特性}

図 7 に圧縮強度と加熱温度の関係を示寸。圧縮強度は加熱温度 $300^{\circ} \mathrm{C}$ までは同程度であり, その後は, 加熱温度の上昇とともに直 線的に低下している。

図 8 にヤング係数と加熱温度の関係を示す。ヤング係数は温度の 影響を大きく受けるとされている ${ }^{7), 8)}$ 。本研究では, 加熱温度 $100^{\circ} \mathrm{C}$ で若干低下し，その後は，加熱温度の上昇とともにヤング係数が急 激に低下している。 


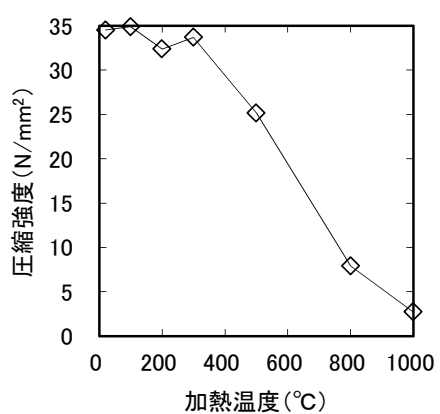

図 7 圧縮強度と 加熱温度の関係

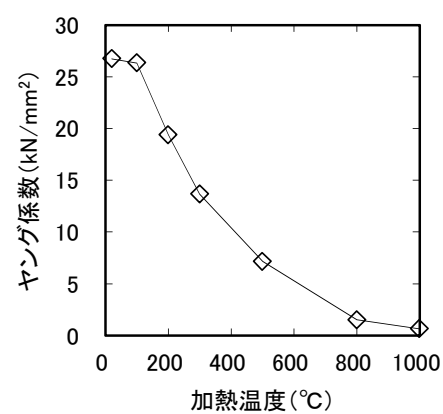

図 8 ヤング係数と 加熱温度の関係

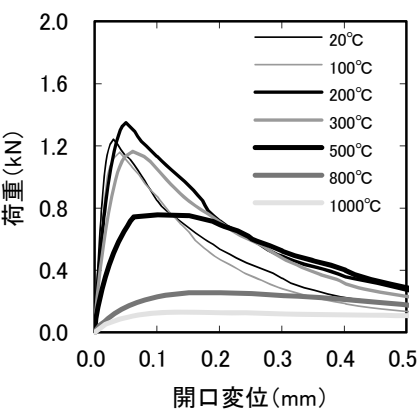

図 9 くさび割裂試験による 荷重一開口変位曲線

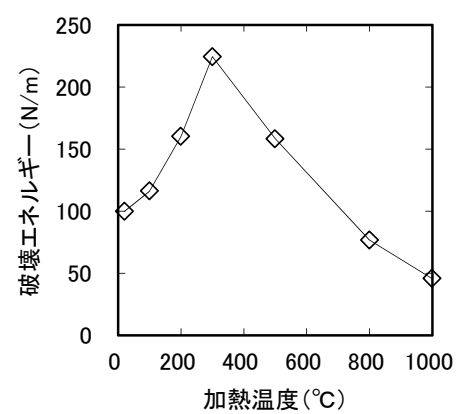

図 10 破壊エネルギーと 加熱温度の関係

表 5 アンダーカット式アンカーの引抜き破壊形状（埋め込み深さ $40 \mathrm{~mm}$ ）

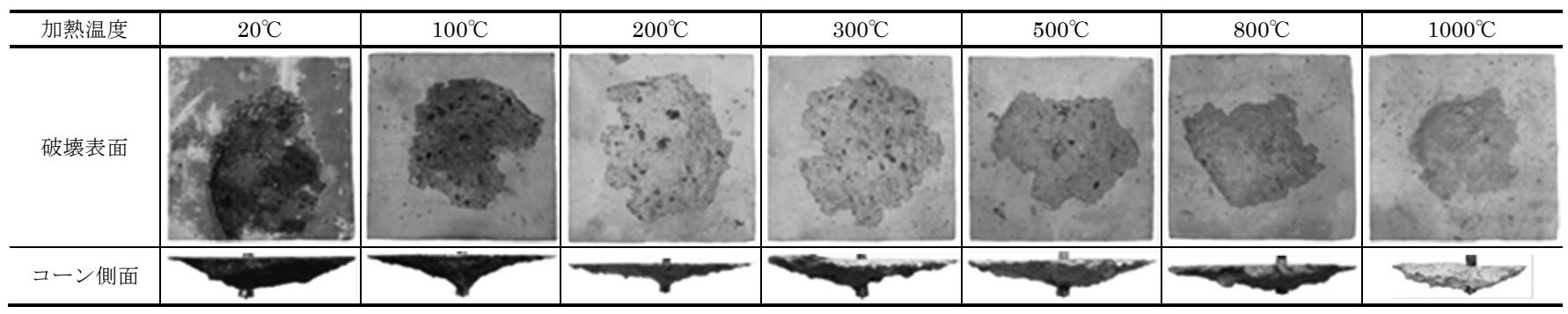

\section{2 コンクリートの破壊特性}

\section{2.1 荷重一開口変位曲線}

図 9 にくさび割裂試験により得られた荷重一開口変位曲線を示す。 加熱の有無や加熱温度に関係なく, 全ての供試体で安定した荷重一 開口変位曲線が得られた。最大荷重は加熱を行なわなかった供試体 $\left(20^{\circ} \mathrm{C}\right)$ と比較して, 加熱温度 $100^{\circ} \mathrm{C}$ で若干低下した後, $200^{\circ} \mathrm{C} て ゙$ 増加して最大となっている。その後は, $300^{\circ} \mathrm{C} て ゙ ~ 100^{\circ} \mathrm{C}$ 同程度ま で低下し， $500 ， 800 ， 1000^{\circ} \mathrm{C}$ と加熱温度が上昇するとともに急激 に低下している。また, 最大荷重時のグラフ形状は, 加熱温度が低 い場合は尖っているが，加熱温度が高くなると次第に丸みを帯びる ように変化し, 最大荷重以降の荷重低下も加熱温度が低い場合は急 勾配だが，加熱温度の上昇とともに緩やかな低下となっている。

\section{2.2 破壊エネルギ一}

図 10 にくさび割裂試験における荷重一開口変位曲線を基に, 多 直線近似解析法によって求めた引張軟化曲線から算出された破壊工 ネルギーと加熱温度の関係を示す。破壊エネルギーは, 加熱温度 $300^{\circ} \mathrm{C}$ までは増加していき, その後は加熱温度の上昇とともに直線 的に低下している。

破壊エネルギーは引張軟化曲線で囲まれた面積であるが，初期結 合応力が大きく, 開口変位の増加にともなう結合応力の低下が緩や かな場合に值が大きくなる。開口変位の増加にともなう結合応力の 低下が緩やかとなる要因としては, 加熱による微細ひび割れの発生 が影響していることが考えられる。ひび割れが進展する際には，ひ び割れ先端に破壊進行領域が形成される。その部分に久陥が存在し なければ骨材などの影響を受けるものの，コンクリート中のひび割 れはほぼ直線的に進展していく。しかし, 微細ひび割れなどの欠陥 が存在する場合には, ひび割れは, その微細ひび割れを介して進展 するために, 破壊が蛇行し, その結果, 破壊に要するエネルギーが 大きくなると思われる。
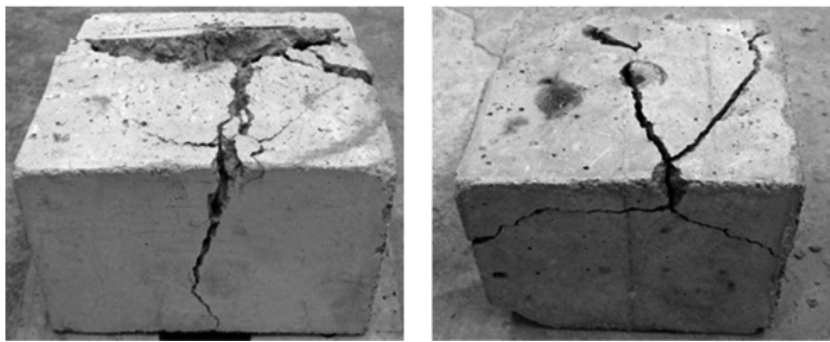

写真 2 アンカー引抜き時に割裂破壊した供試体

\section{3 アンカーの引抜き特性}

\section{3.1 破壊特性}

表 5 にアンカーの引抜き破壊形状の例として，アンダーカット式 アンカーの埋め込み深さ $40 \mathrm{~mm}$ の破壊形状を示す。芯棒打込み式, アンダーカット式ともに，ほとんどがコーン状破壊となったが，加 熱温度 $200^{\circ} \mathrm{C}$ 以上では割裂破壊もみられた（写真 2 )。高温加熱によ りコンクリートの引張強度が低下したためであると考えられる。な お，コーン状破壊をした供試体は，加熱温度が低いと破壊先端部の コンクリートの形状が鋭角だが，加熱温度の上昇とともに先端部の 形状が緩やかとなり，コーンも下側（母材側）に膨らむ傾向にある。

図 11 に各アンカーのコンクリート表面の破壞面積と加熱温度の 関係を示す。なお，本研究における破壊面積は，コーン破面の水平 投影面積である。また，データが示されていない箇所は，アンカー の引抜き時に供試体が割裂破壞し，破壊面積が計測できなかったた めである。

芯棒打込み式, アンダーカット式とも, 埋め込み深さや加熱温度 との関係について，明確な傾向はみられない。これは，高温加熱に よりコンクリートの特性が変化するが，特に，表層部は影響が大き いためであると思われる。なお，グラフはコーン状破壊となった供 試体の平均值を示しているが, 同条件下でもばらつきは大きかった。 


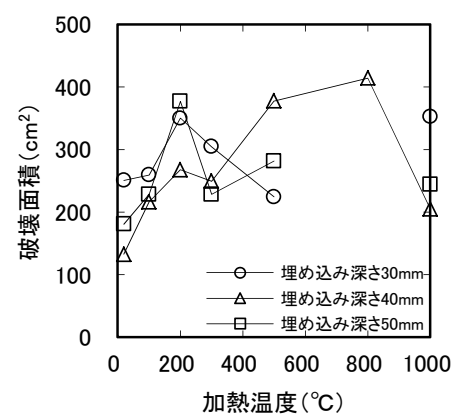

(a) 芯棒打込み式

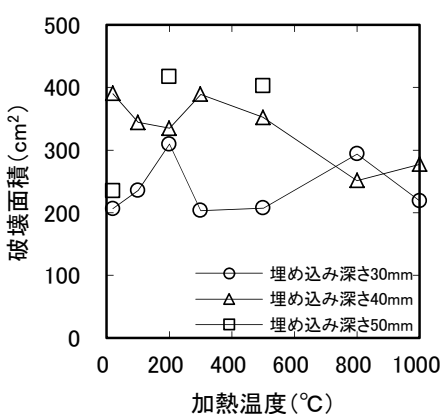

(b) アンダーカット式

図 11 破壊面積と加熱温度の関係

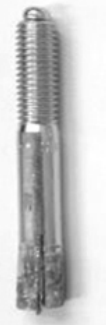

$20^{\circ} \mathrm{C}$

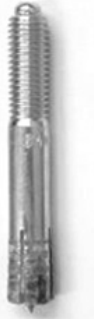

$100^{\circ} \mathrm{C}$

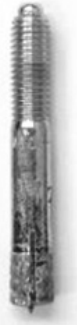

$200^{\circ} \mathrm{C}$

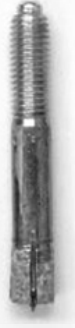

$300^{\circ} \mathrm{C}$

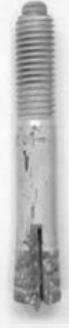

$500^{\circ} \mathrm{C}$

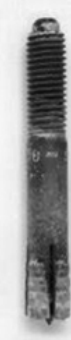

$800^{\circ} \mathrm{C}$

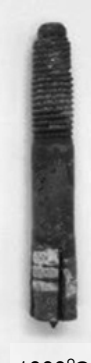

$1000^{\circ} \mathrm{C}$

写真 3 加熱および引抜き試験後のアンダーカット式アンカー

（埋め込み深さ $40 \mathrm{~mm}$ )

図 12 に各アンカーの破壊深さと加熱温度の関係を示す。なお, 本研究における破壊深さは，コーン状破壊した際に，コンクリート 塊がアンカーに付着していた部分の長さとした。また, データが示 されていない箇所は，アンカーの引抜き時に供試体が割裂破壊し， 破壞面積と同様に破壊深さが計測できなかったためである。

芯棒打込み式アンカーの場合は, 加熱温度の上昇とともに若干で はあるが破壊深さが大きくなる傾向がみられる。これは，高温加熱 によりコンクリート強度が低下し, その結果, アンカーの摩擦によ る定着力がコンクリート強度を上回ることで，引抜き時のアンカー の寸べり量が小さくなったと考えられる。アンダーカット式アンカ 一の場合は, 埋め込み深さ $50 \mathrm{~mm}$ のデータが異なっているが, コン クリートが加熱されても破壊深さはほとんど変化しない傾向にある。 これは，アンダーカット式アンカーは，アンカー拡張部に相当する 位置に拡張部が適合するような拡大穴を穿孔して定着するため，芯 棒打込み式アンカーで起こるような摩擦によるすべりが少ないもの と考えられる。

写真 3 に加熱後のアンカーの例として, 引抜き試験を終えた埋め 込み深さ $40 \mathrm{~mm}$ のアンダーカット式アンカーを示す。加熱の有無に よるアンカー自体の大きな変形などは確認されなかった。しかし, 加熱温度の上昇とともにアンカー表面に施されているメッキの変色 が確認された。また, 加熱温度 $800^{\circ} \mathrm{C}$ 以上では, メッキ部分の膨張 も確認された。

図 13 にアンカー拡張部の径と加熱温度の関係を示す。アンダー カット式アンカーで拡張部の径に若干のばらつきがみられるが, 高 温加熱によってアンカー拡張部が, 収縮や膨張などの影響を受ける ことはないものと思われる。

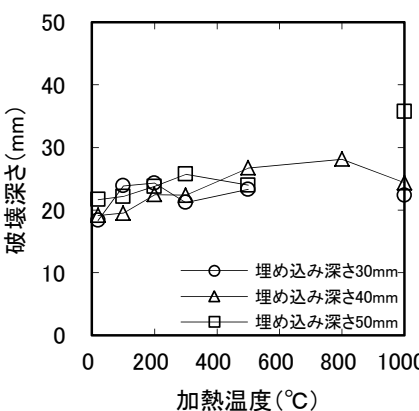

(a) 芯棒打込み式

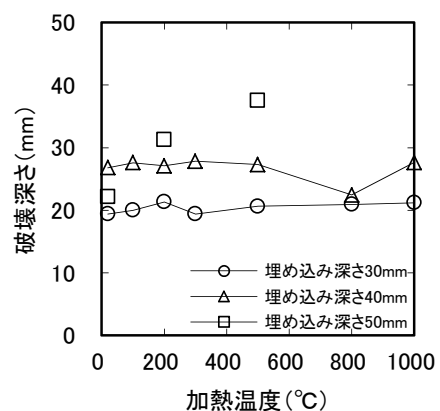

(b) アンダーカット式
図 12 破壊深さと加熱温度の関係

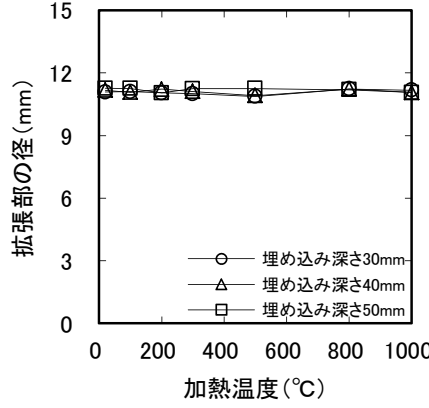

（a）芯棒打込み式

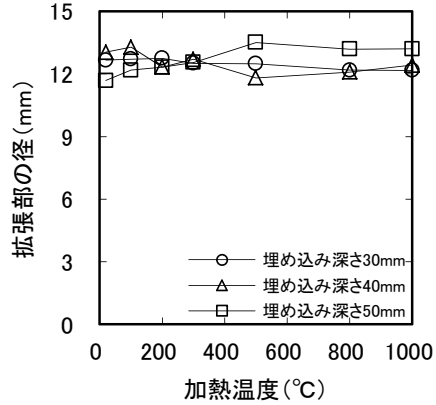

(b) アンダーカット式
図 13 拡張部の径と加熱温度の関係

\section{3. 2 引抜き特性}

図 14 および図 15 に各加熱温度におけるそれぞれのアンカー引抜 き時における荷重一変位曲線を示す。載荷初期は, 芯棒打込み式ア ンカーの勾配が急であるのと比較して，アンダーカット式アンカー は緩やかである。これは, アンカーの定着方法が異なるためである と考えられる。芯棒打込み式アンカーは，拡張部がコンクリート削 孔部を押し広げるように定着するのに対し，アンダーカット式アン カーは, 拡張部が適合するような拡大穴を穿孔して定着するため, 初期のアンカーの定着力が異なっていると思われる。

また, 荷重上昇後は, 芯棒打込み式アンカーの荷重低下が緩やか なのに対し，アンダーカット式アンカーは比較的早く荷重が低下し ている。アンダーカット式アンカーは最大荷重後に破壊が進行する が, 芯棒打込み式アンカーは最大荷重後, その荷重を維持したまま アンカーと定着部である程度すべりが生じていると考えられる。

高温加熱の影響に関しては, 両アンカーとも加熱温度の上昇とと もに, 最大荷重後の荷重低下が緩やかになっている。これは, 高温 加熱によりコンクリートに微細なひび割れが生じたため, 引抜きに よる破壊が直線的に進展せずに微細なひび割れを介して蛇行しなが ら進展したためであると考えられる。

\section{3.3 引抜き荷重}

図 16 に引抜き荷重と加熱温度の関係を示す。芯棒打込み式アン カーは, 加熱温度 $300^{\circ} \mathrm{C}$ まで引抜き荷重の変化は小さく, $20^{\circ} \mathrm{C}$ と比 較して $\pm 10 \%$ の範囲を推移している。そして, 加熱温度 $300^{\circ} \mathrm{C}$ 以降 になると，引抜き荷重は急激に低下し， $500^{\circ} \mathrm{C}$ で $60 \sim 90 \%, 800^{\circ} \mathrm{C}$

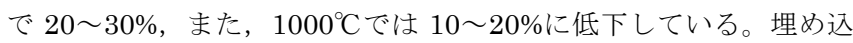
み深さが深いほど, 加熱温度の上昇にともなう荷重低下は小さい。 


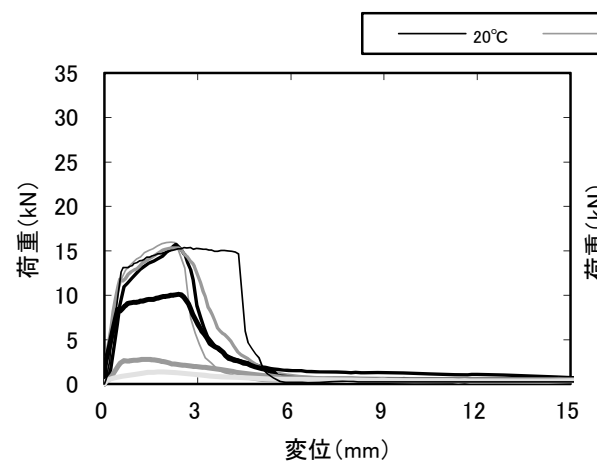

(a) 埋め込み深さ $30 \mathrm{~mm}$

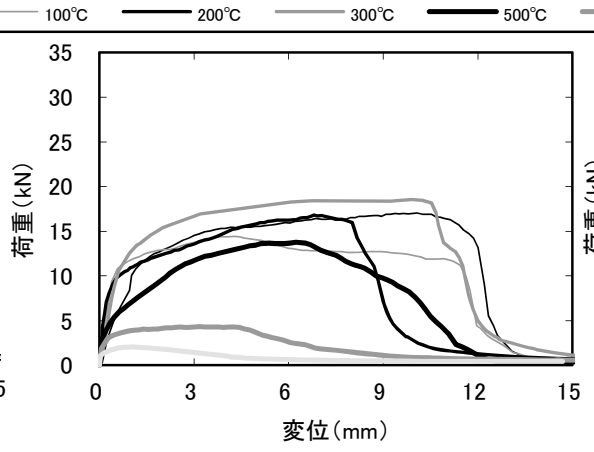

(b) 埋め込み深さ $40 \mathrm{~mm}$

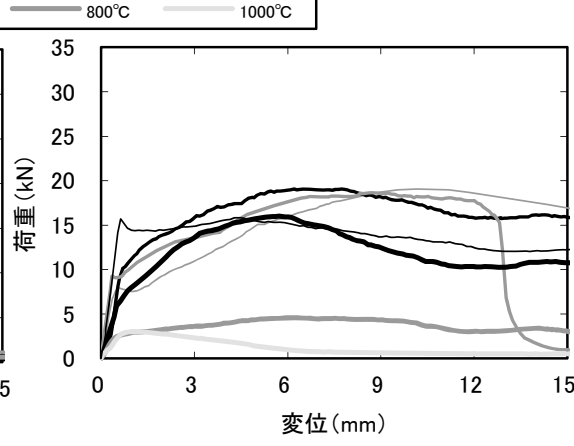

（c）埋め込み深さ $50 \mathrm{~mm}$

図 14 各加熱温度における芯棒打込み式アンカーの荷重一変位曲線

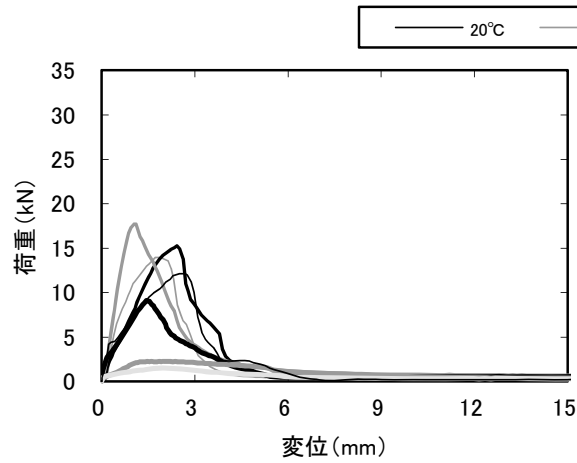

（a）埋め込み深さ $30 \mathrm{~mm}$

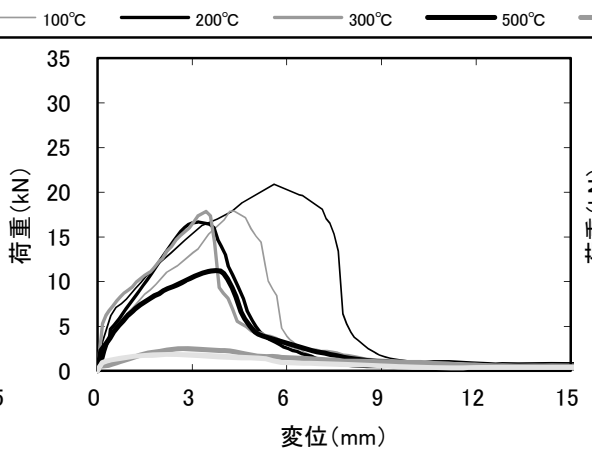

(b) 埋め込み深さ $40 \mathrm{~mm}$

図 15 各加熱温度におけるアンダーカット式アンカーの荷重一変位曲線

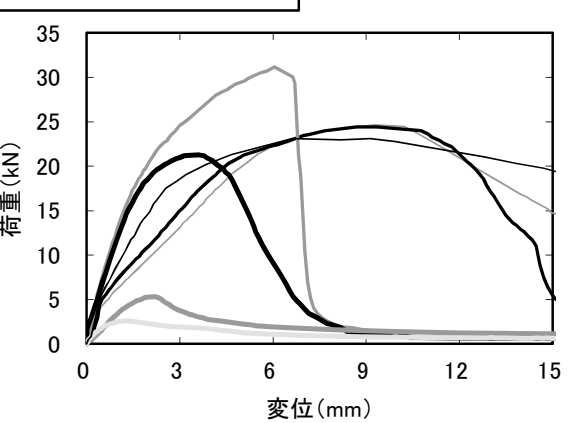

（c）埋め込み深さ $50 \mathrm{~mm}$
アンダーカット式アンカーは, $20^{\circ} \mathrm{C}$ の抜き荷重と比較して, 埋 め込夕深さ $40 \mathrm{~mm}$ では加熱温度 $200^{\circ} \mathrm{C}$ まで引抜き荷重が低下し, $300^{\circ} \mathrm{C}$ で再び増加している。一方, 埋め込み深さ $30 \mathrm{~mm}$ および $50 \mathrm{~mm}$ では $300^{\circ} \mathrm{C}$ まで増加している。なお, その増加は $300^{\circ} \mathrm{C} て ゙ ~ 140 \%$ 程 度である。アンカーの引抜き荷重は, 埋め込み深さにより, 加熱温 度 $300^{\circ} \mathrm{C}$ までは挙動が異なるものの, $300^{\circ} \mathrm{C}$ 以降では芯棒打込み式 アンカーの場合と同様に, 引抜き荷重は急激に低下し， $500^{\circ} \mathrm{C}$ で 55 〜 95\%，800 80 C゙ $14 \sim 24 \%$, そして, $1000^{\circ} \mathrm{C}$ では 9 $12 \%$ まで低下 している。

高温加熱の影響を受けたコンクリートは破壊特性が変化し，ひび 割れ進展抵抗性を示す破壊エネルギーは，養生条件や加熱時間によ って異なるものの，加熱温度 $300 \sim 500^{\circ} \mathrm{C}$ で最大となっている 16)-19), 33)。本研究においても, 破壊エネルギーは加熱温度 $300^{\circ} \mathrm{C}$ で最 大となっており（図 10）, アンカーの引抜き荷重とコンクリートの 破壊エネルギーには, 関係性があると考えられる。そこで, アンカ 一の引抜き荷重とコンクリートの破壊エネルギーの関係性について 後述することとする。

\section{4 アンカーの引抜き荷重と圧縮強度の関係}

図 17 に高温加熱後のそれぞれのアンカーの引抜き荷重とコンク リートの圧縮強度の関係を示す。芯棒打込み式, アンダーカット式 のどちらの金属系アンカーを用いた場合も，既往研究 ${ }^{34)}$ と同様に， 高温加熱の影響を受けた場合でも，アンカーの引抜き荷重とコンク リートの圧縮強度との間には相関があることがわかる。
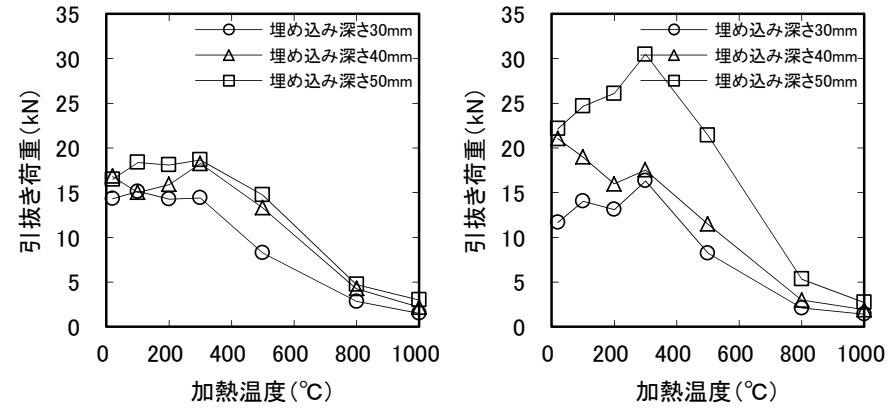

(a) 芯棒打込み式

(b) アンダーカット式

図 16 引抜き荷重と加熱温度の関係

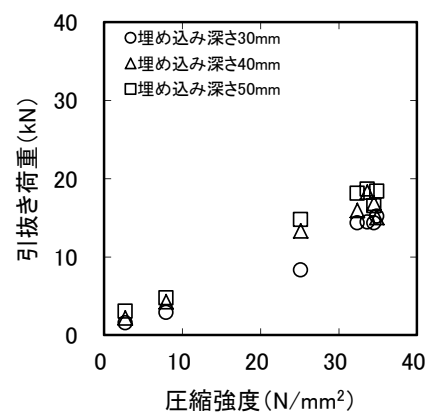

（a）芯棒打込み式

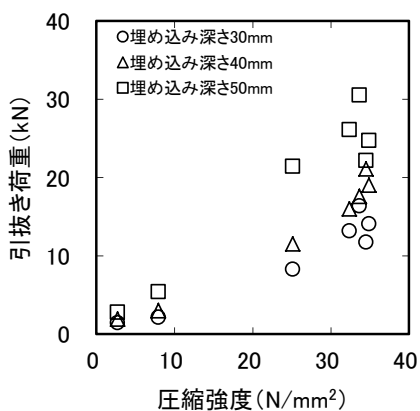

(b) アンダーカット式
図 17 引抜き荷重と圧縮強度の関係 


\section{5 アンカーの引抜き荷重と破壊エネルギーの関係}

アンカーの引抜き特性に関する解析的研究としては, 有限要素法 を用いた検討が多くなされているが，破壊力学を用いた検討は少な

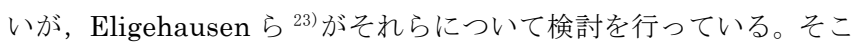
では，頭付きアンカーを用いた検討を行っており，アンカーの引抜 き時の最大荷重と破壊エネルギーの関係を式(1)で表している。

$$
F_{\max }=f(\xi) \cdot\left(E_{\mathrm{C}} \cdot G_{\mathrm{F}}\right)^{0.5} \cdot h_{\mathrm{V}}{ }^{1.5}
$$

ここに, $F_{\max }$ : アンカー引抜き時の最大荷重,

$f(\xi)$ : アンカー引抜き時の荷重一ひび割れ進展関係から 求めた最大值 $(=2.1)$

$E_{\mathrm{C}}:$ コンクリートのヤング係数,

$G_{\mathrm{F}}:$ コンクリートの破壊エネルギー,

$h_{\mathrm{V}}:$ アンカーの埋め込み深さ

図 18 に本研究で得られた芯棒打込み式およびアンダーカット式 の 2 種類のアンカーについての実測值と, Eligehausen らにより提 案された式(1)により算出された計算值との関係を示す。この図を みると, どちらのアンカーを使用した場合でも，実測值と計算值は 概ね比例関係にあることがわかる。また, 本研究では母材に関して, 高温加熱の影響を受けたコンクリートを対象としていることから， 高温加熱の影響を受けた場合でも, アンカーの引抜き荷重と破壊エ ネルギーには相関があるものと推察される。しかし, 実測值と計算 值を比較すると, $1: 1$ の対応とはなっておらず, 計算值の方が大き くなっている。これには, 用いるアンカーの種類や, それにともな う引抜き特性の違い, アンカーの径や埋め込み深さ, また, コンク リートの特性など様々な要因が考えられる。これらの関係に関して は，今後の課題とする。

\section{4. まとめ}

本研究では, $100^{\circ} \mathrm{Cから} 1000^{\circ} \mathrm{C}$ までの高温環境下に一定時間曝さ れたコンクリートに埋め込まれた金属系アンカーの引抜き特性につ いて検討を行った。また, アンカーの引抜き荷重を評価する方法と して, 破壊力学的手法を用いて, 引抜き荷重と破壊パラメータとの 関係について考察を行った。その結果, 本研究の範囲内で以下のこ とが明らかとなった。

（1）アンカーの引抜き破壊形状は, 芯棒打込み式, アンダーカット 式の両アンカーとも, 多くがコーン状破壊となるが, 加熱温度 $200^{\circ} \mathrm{C}$ 以上では割裂破壊となる場合もある。また, 加熱温度が 低いとアンカー拡張部である破壊先端部のコンクリートの形 状が鋭角であるが，加熱温度が上昇するとともに先端部の形状 が緩やかとなり，コーンも，下側（母材側）に膨らむような形 状になる傾向にある。

（2）表面の破壊面積と，埋め込み深さや加熱温度との関係について は, 明確な関係性はみられない。また, 破壊深さと加熱温度の 関係は, 芯棒打込み式アンカーは加熱温度の上昇とともに若干 ではあるが破壊深さが大きくなり，アンダーカット式アンカー は加熱されても破壊深さはほとんど変化しない傾向にある。

（3）加熱の有無によるアンカー自体の変形などは見られないが，加 熱温度の上昇とともにアンカー表面に施されているメッキの変 色, また, 加熱温度 $800^{\circ} \mathrm{C}$ 以上では, メッキ部分の膨張が確認 できる。

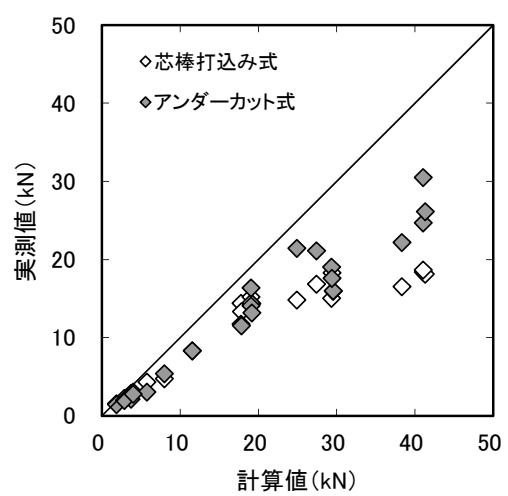

図 18 アンカーの引抜き荷重の実測值と計算値との関係

（4）アンカーの引抜き特性は, 両アンカーとも加熱温度の上昇とと もに，最大荷重後の荷重低下が緩やかになる。

（5）芯棒打込み式アンカーの引抜き荷重は，加熱温度 $300^{\circ} \mathrm{C}$ までの 変化は小さいが， $300^{\circ} \mathrm{C}$ 以降になると急激に低下寸る。なお， 埋め込み深さが深いほど, 加熱温度の上昇にともなう荷重低下 は小さい。

（6）アンダーカット式アンカーの引抜き荷重は，埋め込み深さによ り, 加熱温度 $300^{\circ} \mathrm{C}$ までは挙動が異なるが, $300^{\circ} \mathrm{C}$ 以降では芯 棒打込み式アンカーと同様に急激に低下寸る。

（7）高温加熱後のアンカーの引抜き荷重と, コンクリートの圧縮荷 重の関係には相関がある。

（8）既往の提案式により，アンカーの引抜き荷重とコンクリートの 破壊力学パラメータである破壊エネルギーの関係について検 討した結果, 計算值と実測值は, 概ね比例関係にある。また, この比例関係は，高温加熱の影響を受けた場合にも適応できる と推察される。

\section{謝辞}

本研究を実施するにあたり, サンコーテクノ(株) 八木沢康衛氏に 多大なるご協力をいただきました。記して謝意を表します。

\section{参考文献}

1）日本建築学会：原子炉建屋構造設計指針・同解説，1988

2）岸谷孝一, 嵩英雄, 椎葉大和, 奥野亨 : 各種セメントモルタルの耐熱性 に関寸る研究, 日本建築学会大会学術講演梗概集, pp.157-158, 1971.11

3）岸谷孝一，嵩英雄，奥山治也，奥野亨 : $20 \sim 300^{\circ} \mathrm{C}$ の高温にさらされた コンクリートの諸性状に関する研究 その 1 , 日本建築学会大会学術講演 梗概集，pp.143-144，1972.10

4）岸谷孝一，嵩英雄，奥山治也，奥野亨： $20 \sim 300^{\circ} \mathrm{C}$ の高温にさらされた コンクリートの諸性状に関する研究 その 2 , 日本建築学会大会学術講演 梗概集，pp.145-146，1972.10

5）長尾覚博，中根淳：高温履歴を受けるコンクリートの物性に関する実験 的研究, 日本建築学会構造系論文集, No.457, pp.1-10, 1994.3

6）廣永道彦, 蔵重勲, 井元晴丈：セメント硬化体の熱影響に関する検討一 温度 $65^{\circ} \mathrm{C}$ におけるセメント系材料の変質状況について一, 電力研究所報 告, N04013, 2004

7）安部武雄, 古村福次郎, 戸祭邦之, 黒羽健嗣, 小久保勲：高温度におけ る高強度コンクリートの力学特性に関する基礎的研究, 日本建築学会構 造系論文集，No.515，pp.163-168，1999.1

8）松戸正士，西田浩和, 片寄哲務, 安部武雄 : 高温加熱後の超高強度コン クリートの力学的性質に関する実験的研究, 日本建築学会構造系論文集, No.603, pp.171-177, 2006.5 
9）本田義博, 大岡督尚, 藤巻敏之 : 高強度コンクリートの耐火性能に関す る実験的研究, その 1 定常温度の一軸試験, 日本建築学会大会学術講演 梗概集，A-2 分冊, pp.23-24, 1996.9

10）河辺伸二, 一瀬賢一, 川口徹, 長尾覚博 : 高温加熱を受けたコンクリー トの強度特性に関する研究, コンクリート工学年次論文報告集, Vol.25, No.1, pp.377-382, 2003

11) Sammy Y. N. Chan, Gai-fai Peng and John K. W. Chan : Comparison between high strength concrete and normal strength concrete subjected to high temperature, Materrial and Structure, Vol.29, pp.616-619, 1996.12

12) A. N. Noumowe, P. Clasters, G. Debicki, M. BolvinY. : High Temperature Effect on High Performance Concrete (70-600C) Strength and Porosity, SP-145 Durability of Concrete, Third International Conference, pp.157-172, 1994

13) P. A. Jahren : Fire Resistance of High Strength/Dense Concrete with Particular Reference to the Use of Condensed Silica Fume, SP-114, pp.1013-1049, 1989

14) Binsheng Zhang, Nenad Bicanic, Christopher J. Pearce, and Gojko Balabanic : Assessment of Toughness of Concrete Subject to Elevated Temperatures from Complete Load-Displacement Curve-Part II Experimental Investigations , ACI Materials Journal , September-October, pp.556-566, 2000

15) Binsheng Zhang and Nenad Bicanic : Residual Fracture Toughness of Normal- and High-Strength Gravel Concrete after Heating to $600^{\circ} \mathrm{C}$, ACI Materials Journal, May-June, pp.217-226, 2002

16) B. Zhang, N. Bicanic, C. J. Pearce and G. Balabanic: Residual fracture properties of normal- and high-strength concrete subjected to elevated temperatures, Magazine of Concrete Research, 52, No.2, Apr., pp.123-136, 2000

17) Jiangtao $\mathrm{Yu}$, Kequan $\mathrm{Yu}$, Zhoudao $\mathrm{Lu}$ : Residual fracture properties of concrete subjected to elevated temperatures, Materials and Structures, DOI 10.1617/s11527-012-9823-4, 2012

18）松沢晃一, 橘高義典: 高温加熱の影響を受けたコンクリートの破壊特性, 日本建築学会構造系論文集，No.680，pp.1477-1483，2012.10

19）松沢晃一, 橘高義典：高温加熱の影響を受けたコンクリートの破壊特性 に及ぼす材齢および養生の影響, 日本建築学会構造系論文集, No.688, pp.1027-1034, 2013.6

20) 日本建築学会 : 各種合成構造設計指針・同解説（改定）, 2010

21）橋本純, 滝口克己 : 熱を受けるコンクリート埋め込みボルトの引抜きに 関する実験，日本建築学会構造系論文集，No.568, pp.123-129，2003.6
22）寺島悟, 沢出稔, 丹羽亮, 秋山友昭, 松崎育弘 : 加熱されたコンクリー 卜の耐火性評価とあと施エアンカーに関する研究，その 1 ，一面 3 時間 加熱, 日本建築学会大会学術講演梗概集, C 分冊, pp.691-692, 1994.9

23) Eligehausen. R and Sawade. G. : A fracture mechanics based description of the pull-out behavior of headed studs embedded in concrete, RILEM report, Fracture Mechanics of Concrete Structures, Chapman and Hall, pp.281-299, 1989

24）橘高義典, 上村克郎, 高瀬克憲 : 高強度コンクリートのボルト引抜き耐 力に及ぼす粗骨材種類の影響, コンクリート工学年次論文報告集，第 13 巻, 第 1 号, pp.245-250, 1990.6

25) RILEM AAC13.1 : Determination of the specific fracture energy and strain softening of AAC, RILEM Recommendations for the Testing and Use of Constructions Materials, pp.156-158, 1994

26）切欠きはりを用いたコンクリートの破壊エネルギー試験方法, JCI-S-001-2003

27）橘高義典, 高橋仁智 : 破壊力学手法によるひび割れ分散を考慮した繊維 補強軽量コンクリートパネルの曲げ破壊解析, 日本建築学会構造系論文 集, No.541, pp.37-42, 2001.3

28）神山力，橘高義典，田村雅紀 : 各種コンクリートの破壊特性の試験方法 に関する研究，コンクリート工学年次論文集，Vol23，No.3，pp.91-96， 2001

29) RILEM AAC13.1 : Determination of the specific fracture energy and strain softening of AAC, RILEM Recommendations for the Testing and Use of Constructions Materials, pp.156-158, 1994

30）橘高義典, 上村克郎, 中村成春 : コンクリートの引張軟化曲線の多直線 近似解析，日本建築学会構造系論文報告集，No.453，pp.15-25，1993.11

31）橘高義典：引張軟化曲線の多直線近似解析によるコンクリートの弾塑性 破壞パラメータの評価, 日本建築学会構造系論文集, No.469, pp.17-24, 1995.3

32) G. V. Guinea, M. Elices and J. Planas : Stress Intensity Factors for Wedge-splitting Geometry, Int. J. of Fract. 81, pp.113-124, 1996

33) Graham Baker : The effect of exposure to elevated temperatures on the fracture energy of plain concrete, Materials and Structures, Vol.29, pp.383-388, 1996

34）清水泰, 遠藤利根穂 : あと施工アンカーの引き抜き耐力に関する実験研 究, 日本建築学会大会学術講演梗概集, C 分冊, pp.595-596, 1987.10 


\title{
INFLUENCE OF HIGH TEMPERATURE HEATING ON PULL-OUT PROPERTIES OF MECHANICAL ANCHOR EMBEDDED IN CONCRETE
}

\author{
Koichi MATSUZAWA*, Yoshinori KITSUTAKA** and Akihiko KATTA*** \\ * Assist. Prof., Dept. of Architecture and Building Engineering, Graduate School of Urban Environmental Sciences, Tokyo Metropolitan Univ., M. Eng. \\ ** Prof., Dept. of Architecture and Building Engineering, Graduate School of Urban Environmental Sciences, Tokyo Metropolitan Univ., Dr. Eng. \\ ${ }_{* * *}$ Graduate Student, Dept. of Architecture and Building Engineering, Tokyo Metropolitan Univ.
}

Surface layer of concrete becomes the most heavily damaged part affected by high temperature heating when concrete structure is subjected to fire accident. In the surface layer of concrete structures, the anchor bolts are used for fixing the equipment or the seismic strengthening elements. There are large variety of concrete anchors and construction methods in anchorage. And many design recommendations are published. About the anchors used for many situations, there are some investigations on pull-out behavior of chemical anchors subjected to high temperature heating. However, the properties on metal-based mechanical anchors affected by high temperature heating have not been cleared.

In this research, the influence of high temperature heating up to $1000^{\circ} \mathrm{C}$ on pull-out properties of two types of mechanical anchors, which were a hammer drive anchor and an undercut anchor, embedded in concrete was investigated. Relationship between the pull-out strength of anchors and the fracture energy was also investigated.

Follow conclusions were found within the range of this study

(1) Failure mode of both the hammer drive anchor and the undercut anchor, loaded in tension was almost the cone type failure. However, the splitting type failure was observed when specimens were heated over $200^{\circ} \mathrm{C}$.

(2) Relationships between the heating temperature and the surface failure area or the anchorage depth were not clarified. The failure depth of hammer drive anchor tended to become deeper with the increase of heating temperature, but the failure depth of undercut anchor extensively changed with the increase of heating temperature.

(3) The deformation of anchor by heating was not confirmed, but the color of gilding was changed with a temperature rising and expanded over $800^{\circ} \mathrm{C}$.

(4) Regard to load-displacement curves, the load reduction after the maximum load became gradual by the increase of heating temperature.

(5) The pull-out strength of hammer drive anchor a little changed up to a heating temperature of $300^{\circ} \mathrm{C}$, but decreased as the heating temperature beyond $300^{\circ} \mathrm{C}$

(6) The pull-out strength of undercut anchor was changed by accordance of an anchorage depth up to a heating temperature of $300^{\circ} \mathrm{C}$

(7) There is an association between the pull-out strength of anchor bolt subjected to high temperature heating and compressive strength of concrete.

(8) Good correspondence was obtained between an actual value observed by the experiment and the theoretical value calculated by the homer evaluation formula substituting the pull-out strength and fracture energy. In addition, it was suggested that the formula could predicting the pull-out strength of anchor bolts under the condition of high temperature heating.

（2014年 4 月10日原稿受理，2014年 9 月17日採用決定） 